\title{
Determination of Total Flavonoid Levels of Ethanol Extract Sesewanua Leaf (Clerodendrum Fragrans Wild) With Maceration Method Using UV-Vis Spectrofotometry
}

\author{
Zulfiayu Sapiun ${ }^{1, *}$, Paulus Pangalo², Arlan K. Imran ${ }^{1}$, Prisca Safriani Wicita', Rizka Puji Astuti Daud'
}

Zulfiayu Sapiun ${ }^{1, *}$, Paulus Pangalo², Arlan K. Imran', Prisca Safriyani Wicita', Rizka Puji Astuti Daud $^{1}$

'Pharmacy Department, Health Polytechnic of Gorontalo, INDONESIA.

${ }^{2}$ Nursing Department, Health Polytechnic of Gorontalo, INDONESIA.

\section{Correspondence}

\section{Zulfiayu Sapiun}

Pharmacy Department, Health Polytechnic of Gorontalo, INDONESIA.

Phone no: +6281244521639

E-mail: zulfiayu@poltekkesgorontalo.ac.id History

- Submission Date: 28-11-2019;

- Review completed: 15-12-2019;

- Accepted Date: 10-01-2020.

DOI : 10.5530/pj.2020.12.56

Article Available online

http://www.phcogj.com/v12/i2

Copyright

(C) 2020 Phcogi.Com. This is an openaccess article distributed under the terms of the Creative Commons Attribution 4.0 International license.

\begin{abstract}
Introduction: Sesewanuwa (Clerodendrum fragrans Wild) is one of the plants with abundant flavonoid content in the leaves. The characteristic flavonoids with the two benzene ring groups cause the process of finding an appropriate extraction technique. Objective: This study aims to determine the total flavonoid levels of ethanol extract of sesewanuwa leaves obtained from maceration extraction methods. Method: This research was carried out by extracting the simplicia of sesewanuwa leaves by maceration method using $96 \%$ ethanol solvent. Comparison between the simplicia and the solvent used is $1: 7$, then the extract obtained was carried out with initial qualitative identification of flavonoids with simple reagents and the total flavonoid levels were determined using UV-Vis spectrophotometry. Results: The results showed that the ethanol extract of sesewanuwa leaves obtained by maceration extraction method in qualitative and quantitative tests contained flavonoids with quercetin standard with a total content of $13.47 \%$. This research was carried out by extracting the simplicia of sesewanuwa leaves by maceration method using $96 \%$ ethanol solvent. Comparison between the simplicia and the solvent used is $1: 7$, then the extract obtained was carried out with initial qualitative identification of flavonoids with simple reagents and the total flavonoid levels were determined using UV-Vis spectrophotometry. Conclusion: The results showed that the ethanol extract of sesewanuwa leaves obtained by maceration extraction method in qualitative and quantitative tests contained flavonoids with quercetin standard with a total content of $13.47 \%$ Key words: Sesewanuwa, Total Flavonoid, Quercetin, Maceration, UV-Vis spectrophotometry.
\end{abstract}

\section{INTRODUCTION}

Sesewanua leaves (Clerodendrum fragrans Wild) contain bioactive compounds such as flavonoids, phenolics, tannins, alkaloids and saponins. ${ }^{1}$ The classification of Sesewanua was king: Plantae, class : Equisetopsida, Ordo: Lamiales, Family : Lamiaceae, Genus: Clerodendrum, Species: Clerodendrum fragrans Wild. Sinonim: Clerodendrum chinense (Osbect), Volkameria fragrans Vent. Local name: Sesewanua, Bulahu. ${ }^{2-4}$ Chemical ingredients of Sesewanua were Tannin $(++)$, Saponin $(++)$, Flavonoid $(++)$, dan Alkaloid $(++),{ }^{1}$ while ${ }^{5}$ only showed possitive in alkaloid and flavonoid. Acteoside, leucosceptoside A, isoacteoside, ester metil dan etil dari asam kafeat, jnoside dan kaempferol, ${ }^{2}$ Uncinatone, Prunasin, Acacetin-7-Ometylgluconate, Clerosterol, Neolignan I, II, dan III, Serratagenic acid, dan Scutellarin. ${ }^{6}$

Clerondrum genus have Larvicidal and Pupicidal activity. ${ }^{7,8}$ In empirical studies, sesewanua used as antitumor, antiinflamation, antipyretic, spa,antioxidant, antiinflamation and antihematome. $^{9-16}$ Sesewanua leaves had been studied for it's antipyretic activity ${ }^{1,10}$ Antioxidant test at etil acetate, etanol and n-heksan extract showed that Sesewanua had a strong antioxidant. ${ }^{12}$ It cytotoxic effect to T47D cell found at moderate level. ${ }^{11}$
Flavonoid is a compound which is described as a row of C6-C3-C6 aromatic rings with 2 main characteristics such as oil that is difficult to dissolve in polar solvents (aglycone) and can also be bound to sugars (glycons) which can be easily dissolved in polar solvents. ${ }^{17}$ The characteristic of flavonoids that can be polar and non-polar require proper extraction techniques in carrying out the search.

Macerated extraction method is a simple method of extraction with the principle of immersion and stirring of the sample in a suitable solvent in extracting flavonoid compounds in the sample, compared to other methods in maceration extraction having the advantage of using more solvents than other extraction methods. Optimization that can be done on the maceration method is to vary the ratio of the number of samples and solvents used. Factors that can affect the amount of yield and total levels of extracted compounds include the type of solvent and the amount of solvent used. ${ }^{18}$

Research related to the search for secondary metabolism of sesewanuwa leaves is still in the process of maceration extraction using different solvents and comparison of solvents, namely using ethyl acetate solvent at a ratio of 1: $4^{12}$ and ethanol solvents in a ratio of $1: 3,{ }^{19}$ so this study aims to measure the total flavonoid levels in sesewanuwa leaf extract using maceration extraction methods with

Cite this article: Sapiun Z, Pangalo P, Imran AK, Wicita PS, Daud RPA. Determination of Total Flavonoid Levels of Ethanol Extract Sesewanua Leaf (Clerodendrum Fragrans Wild) With Maceration Method Using UV-VIS Spectrofotometry. Pharmacog J. 2020;12(2):356-60. 
a higher sample and solvent ratio of 1: 7 which more leverage in the search process. ${ }^{18}$

The extract obtained from the extraction process is then calculated its yield, qualitatively identified and determined quantitatively using UVVis spectrophotometry its total flavonoid levels.

\section{METHODS}

The research conducted was an experimental laboratory study. The materials used in this study were leaves of sesewanuwa from Tilango District, Gorontalo Indonesia, ethanol 96\% (CV Chem-Mix), FeCl3 (CV Chem-Mix), quarsetin (CV Chem-Mix), AlCl3 (CV Chem-Mix), potassium acetate (CV Chem-Mix) and Aquadestilata. The research implementation process includes:

\section{Making simplisia sesewanua leaves (Clerodendrum fragrans Wild)}

One $\mathrm{Kg}$ fresh leaves were collected from healthy sesewanuwa at Tilango District, Gorontalo Province, Indoensia during April 2019. The plant sample was identified to be Clerodendum fragrans Wild. by Indonesian Institute of Sciences - Research Center for Plant Conservation and Botanic Garden, Bogor, Indoensia (Reference no.B-418/IPH.3/KS/ II/2019). This leaves are washed washed thoroughly with running water to remove the dirt from these samples. ${ }^{20}$ These samples were blotted dry with tissue papers and carried out chopped with a uniform size, then carried out drying in the oven at $60^{\circ} \mathrm{C}$ for 3 days after drying dry sorting is done to separate the damaged parts and then mashed using a blender to produce simplicia 500 grams of sesewanuwa leaf powder. ${ }^{12}$

The simplisia extraction process of sesewanua leaves (Clerodendrum fragrans Willd) with the maseration method

Weigh as much as $500 \mathrm{~g}$ of simplicia leaves of an animal and then add $96 \%$ ethanol $^{21} 3.5 \mathrm{~L}$ until the simplicia is completely submerged. Extraction was carried out for $3 \times 24$ hours protected from light and stirred every 24 hours. On days 2 and 3 the solvent was filtered for remaseration to obtain 3 filtrates for each solvent. The filtrate was then evaporated with a rotary evaporator to obtain a thick ethanol extract from the leaves of an animal. ${ }^{22}$

\section{Qualitative identification of flavonoid ethanol extract of sesewanua leaves}

Qualitative identification begins with weighing the extract as much as $100 \mathrm{mg}$ dissolved in a mixture of $50 \mathrm{~mL} 96 \%$ ethanol and $50 \mathrm{~mL}$ of water, then heated over a water bath at $60^{\circ} \mathrm{C}$ for 15 minutes. The extract solution in the solvent mixture was put into 6 test tubes each of 3 tubes tested using $10 \% \mathrm{NaOH}$ as much as $5 \mathrm{ml}$ and the other 3 tubes added with $5 \mathrm{ml}$ concentrated acetate $\mathrm{Pb}$ shaken strongly. Observed the changes that occur, if formed yellow, red, brown to test with $\mathrm{NaOH}$ and precipitate formed to test with positive $\mathrm{Pb}$ acetate samples containing flavonoids.

Determination of total flavonoid content of ethanol extract of sesewanua leaf (Clerodendrum fragrans Wild) using UV-Vis spectrophotometry

\section{Making of quercetin raw curve}

$1000 \mathrm{ppm}$ quarsetin mother liquor was made by weighing $25 \mathrm{mg}$ of quercetin dissolved in $25 \mathrm{ml}$ of $96 \%$ ethanol, in a measuring flask. each taken $3 \mathrm{ml}, 4 \mathrm{ml}, 5 \mathrm{ml}, 6 \mathrm{ml}, 7 \mathrm{~mL}, 8 \mathrm{~mL}$ and $9 \mathrm{ml}$ from the mother liquor, put in a $10 \mathrm{~mL}$ measuring flask sufficient with ethanol $96 \%$ to the mark limit. Quercetin levels of $60 \mathrm{ppm}, 80 \mathrm{ppm}, 100 \mathrm{ppm}, 120$ ppm, $140 \mathrm{ppm}, 160 \mathrm{ppm}$ and $180 \mathrm{ppm}$ are obtained. As much as $1 \mathrm{ml}$ of solution taken from each concentration was added $0.1 \mathrm{ml}$ of $\mathrm{AlCl}_{3}, 0.1$ $\mathrm{ml}$ of potassium acetate, $2.8 \mathrm{ml}$ of aquadest and $1.5 \mathrm{ml}$ of $96 \%$ ethanol and allowed to stand for 30 minutes. Its absorbance is read at $415 \mathrm{~nm}$ wavelength using UV-Vis spectrophotometry. A standard quartz curve is obtained.

\section{Readings of absorbance samples of sesewanua leaf ethanol extract (Clerodendrum fragrans Wild)}

Weighed as much as $10 \mathrm{mg}$ of ethanol extract from sesewanuwa leaves and dissolved in $10 \mathrm{ml}$ of $96 \%$ ethanol, so a $1000 \mathrm{ppm}$ sample solution was obtained. Sample preparation was carried out by taking $1 \mathrm{ml}$ of 1000 ppm extract solution, added with $0.1 \mathrm{ml}$ of $\mathrm{AlCl}_{3}, 0.1 \mathrm{ml}$ of potassium acetate, $2.8 \mathrm{ml}$ of aquadest, and 1.5 ethanol $96 \% .{ }^{23}$ After that it was allowed to stand for 30 minutes and the absorbance was measured with a UV-Vis spectrophotometer at a maximum wavelength of $415 \mathrm{~nm}$.

\section{RESULTS AND DISCUSSION}

\section{Extract yield extract}

The result of the extraction of simplicia Sesewanua leaves 500 grams with $96 \% 3.5 \mathrm{~L}$ ethanol solvent that has been done was obtained as much as $38 \mathrm{~g}$ of ethanol extract of sesewanuwa leaves, so that the yield of extraction obtained is equal to $7.6 \%$. The results obtained are still better than the number of research ramen ${ }^{12}$ using the same extraction method but different solvents and solvent comparisons, each with 1: 4 ethyl acetate and $\mathrm{n}$ hexane solvents. The yield obtained in the research ${ }^{12}$ was $5 \%$ and $2 \%$ respectively. The increase in the amount of yield obtained from this study was caused by 2 things namely the type of solvent and the ratio of samples and solvents used (Figure 1).

Ethanol solvent has a high polarity value compared to ethyl acetate and $\mathrm{n}$-hexane. The abundant secondary metabolite compounds in the leaves of sesewanuwa are polar compounds so that the use of more sample and solvent comparisons of 1: 7 causes more substances to be found in the ethanol solvent than other solvents. ${ }^{12,24}$

\section{Results of qualitative identification of extracts}

Ethanol extract of positive sesewanua leaves containing flavonoids both tested using $\mathrm{NaOH}$ and $\mathrm{Pb}$ acetate with each marked an intense yellow color and a precipitate formed.

Testing with the addition of $\mathrm{NaOH}$ into the solution will cause a reaction between $\mathrm{Na}+$ ions and $\mathrm{H}+$ ions will bind to $\mathrm{OH}-$ in $\mathrm{NaOH}$ to form $\mathrm{H}_{2} \mathrm{O}$ compounds in the extract, whereas $\mathrm{Na}+$ ions will bind to $\mathrm{O}$ ions in the cyclic groups to form sodium phenoxide compounds which will cause the solution to turn yellow. ${ }^{25,26}$

Testing using $\mathrm{Pb}$ Acetate will produce a white precipitate at the bottom of the tube which is caused by the reaction between the $\mathrm{Pb}^{+}$ion and the hydroxyl group on the cyclic structure of the flavonoids, because $\mathrm{Pb}$ is one of the heavy metals whose properties will always produce a precipitate when reacted (Figure 2). ${ }^{25,26}$

Result of determination of total flavonoid levels of ethanol extract of sesewanua leaves by UV-Vis spectrophotometry

\section{Quercetin raw curve}

Measurement of quercetin standard absorbance as shown in Table 1. produces a linear regression equation $\mathrm{y}=0.0043 \mathrm{x}+0.0196$ with a value of $r=0.9878$. the resulting $r$ value indicates that the standard curve produced has an accuracy of $98.78 \%$, a method is said to be good if the $r$ value produced is close to 1 or in the range $0.95-1$. Furthermore, the linear regression equation is used in determining total flavonoid levels in ethanol extracts of sesewanuwa leaves (Table 2). 


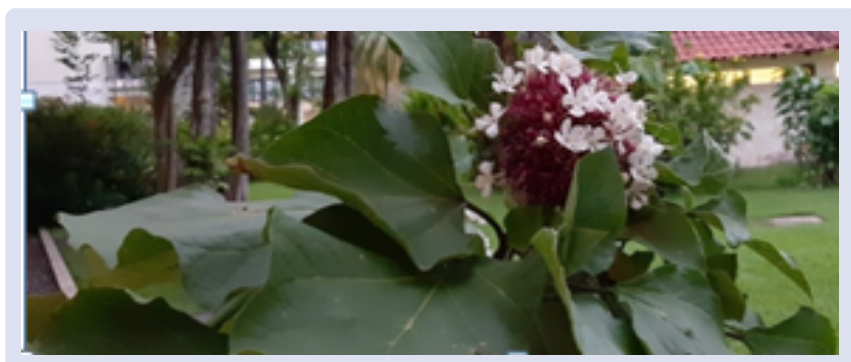

Figure 1: Sesewanua (Clerodendrum fragrans Wild.).

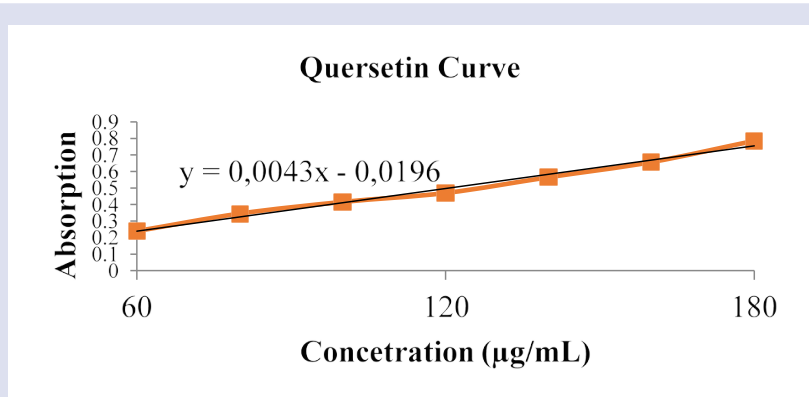

Figure 2: Quantitative test flavonoid ethanol extract of Sesewanua leaf (Clerodendrum fragrans Wild).

Table 1: Results of absorbance of quercetin raw curve.

\begin{tabular}{cc}
\hline Concentration (PPM) & Absorbance \\
\hline 60 & $0.240 \pm 0,0006$ \\
80 & $0.346 \pm 0,0012$ \\
100 & $0.415 \pm 0,0010$ \\
120 & $0.470 \pm 0,0010$ \\
140 & $0.565 \pm 0,0006$ \\
160 & $0.657 \pm 0,0010$ \\
180 & $0.786 \pm 0,0015$ \\
\hline
\end{tabular}

Table 2: Results of absorbance of quercetin raw curve.

\begin{tabular}{cccc}
\hline Absorbance & $\begin{array}{c}\text { Sample Content } \\
\text { (PPM) }\end{array}$ & $\begin{array}{c}\text { Level of Results } \\
\text { (PPM) }\end{array}$ & \% Content \\
\hline 0.560 & 1000 & 134.79 & $13.47 \pm 0,07$ \\
\hline
\end{tabular}

\section{Samples of sesewanuwa leaf ethanol extract}

The results showed that in 1000 PPM the sample concentrations contained 134.79 PPM flavonoids. The results obtained are higher in total flavonoid levels compared to the total number of total flavonoids from leaves of plants that are optimized for the drying temperature of their simplicity. ${ }^{19}$ Hohakay et al showed that fresh leaves, dried leaves, dried at $40^{\circ} \mathrm{C}$ and $60^{\circ} \mathrm{C}$ respectively had total flavonoid levels of $1.2 \%$, $0.72 \%, 0.78 \%$ and $0.62 \%$. The increase in the total amount of flavonoids obtained from this study was due to the comparison of samples and solvents used in the extraction process by maceration method. The factor that can affect the extraction process is the amount of solvent used. ${ }^{18}$ The ratio of samples and solvents used in this study is 1: 7 whereas in research Hohakay et al. only 1: $3 .{ }^{19}$

\section{CONCLUSION}

Ethanol extract of sesewanuwa leaves contains flavonoid compounds and total flavonoid levels of ethanol extract of sesewanuwa leaves extracted by maceration method with a $1: 7$ solvent ratio determined by UV-Vis spectrophotometry method of $13.47 \%$.

\section{ACKNOWLEDGEMENT}

The authors thanks to Health Ministry of Indonesia for financial support in this research.

\section{CONFLICTS OF INTEREST}

None.

\section{REFERENCE}

1. Nonke E, Kaunang S, Semuel MY. Botanical and phytochemical constituents of several medicinal plants from mount Klabat north Minahasa. J Med Plants Stud. 2017;5(2):29-35.

2. Uno WZ. Isolation and Idenfication Antibacterial Activity of leilem Leaves Extract (Clerodendrum minahassae Teijsm. dan Binn.). Hassanuddin University; 2017.

3. WHO. Medicinal plants in Viet Nam (Institute of Materia Medica - HANOI WHOMPRO, 1990, 444 p.): Part II: Medicinal plants: 55. Clerodendrum squamatum Vahl. Institue of Materia Medica, Hanoi. 1990 [cited 2019 Jan 18]. p. 444. Available from: http://www.nzdl.org/gsdlmod?e=d-00000-00---offOwhoedm--00-0---0-10-0---0--0direct-10--4---o-11--11-en-50---20-about---00-01-00-0--4---0-0-11-10-0utfZz-8-00\&a =d\&c=whoedm\&cl=CL1.1\&d=HASH16e13 d8f98944d7e8576f3.3.55

4. Franca F, Atkins S. Neotropical Verbenaceae - Neotropikey from Kew. Kew Royal Botani Garden. 2018.

5. Sangi M, Runtuwene MRJ, Simbala HEI. Phytochemical analysis Herb Plant in North Mihahasa District. Chem Prog. 2008;1(1):47-53.

6. Shrivastava, N. Patel T. Clerodendrum and Heathcare: An Overview. Med Aromat Plant Sci Biotechnol. 2007;1(1):142.

7. Dhal P, Rout JR, Dash PK, Panda S, Pati P, Rath CC, et al. Larvicidal and pupicidal activity of Clerodendrum philippinum schauer leaf extracts against Anopheles stephensi and Aedes aegypti. Pharmacogn J. 2018;10(6):1137-42.

8. Tangsongcharoen T, Issaravanich S, Palanuvej C, Ruangrungsi N. Quantitative analysis of hispidulin content in clerodendrum petasites roots distributed in Thailand. Pharmacogn J. 2019;11(5):1093-9.

9. Simbala H. Floristic and The Use of Medical Plant by Community in Bogani Nani Wartabone National Park. Bogor Agricultural University; 2007.

10. Moot CL, Bodhi W, Mongi J, Farmasi PS. Antipiretic Test of Sesewanua Leaves Water Extract (Clerodendron squamatum Vahl .) to Rabbit that induce by DTP HB Vaccine. Pharmacon. 2013;2(03):58-61.

11. Yudistira A. Cytotoxic Activity Test of Sesewanua Leaves Extract (Clerodendron squmatum Vahl .) to Breast Cancer T47D Cell. Pharmacon . 2017;6(2):45-51.

12. Huliselan YM, Runtuwene MRJ, Wewengkang DS. Antioxidant Activity of Ethanol. Ethyl Acetate, and n-Hexan Extract from ESesewanua Leaves (Clerodendron squamatum Vahl.). Pharmacon J. 2015;4(3):155-63.

13. Shrivastava N, Patel T. Clerodendrum and Healthcare: An Overview - Part II Phytochemistry and Biotechnology. 2007.

14. Jubir AA. ATaxonomic Revision OfThe Genus Clerodendrum L. (VERBENACEAE )* IN AUSTRALIA. Adeleide Bot Gard. 1989;11(2):101-73.

15. Wang J, Luan F, He X, Wang Y, Li M. Journal of Traditional and Complementary Medicine Traditional uses and pharmacological properties of Clerodendrum phytochemicals. J Tradit Chinese Med Sci . 2018;8(1):24-38.

16. Kar P, Goyal AK, Das AP, Sen A. Antioxidant and pharmaceutical potential of Clerodendrum L .: An overview. 2014;(September).

17. K.H M. Method to Identification of Flavonoid. Bandung, Indonesia: Institut Teknolog Bandung; 1988.

18. T A, R C, Fresco A. The Effect of Hexana and Ethanol Solvent, Solvent Volume, and Extraction Time to Coffee Oil Extract. J Tek Kim. 2016;8(1).

19. JJ H, J P, A Y. The effect of drying method to flavonoid level at sesewanua leaves (Clerodendrum squamatum Vahl.). J Imiah Farm. 2019;8(4):24-33.

20. Muthukumaran P, Saraswathy N, Aswitha V, Balan R, Gokhul VB, Indumathi $P$, et al. Assessment of total phenolic, flavonoid, tannin content and phytochemical screening of leaf and flower extracts from Peltophorum pterocarpum (DC.) Backer ex K. Heyne: A comparative study. Pharmacogn J. 2016;8(2):140-3.

21. Mihai $\mathrm{CM}, \mathrm{Al} \mathrm{L}$, Bobi O, Dezmirean D. Estimation of Flavonoid Content in Propolis by Two Different Colorimetric Methods. 2010;43(1):407-10.

22. Nur Ain Thomas, Aslia Sari Alfian MSP. Formualtion and effectivity test of binahong and guava leaves extract as antiinflamation at mus musculus. In: Home Pharmaceutical Care terhadap Penyakit Kronis. Gorontalo: UNG Press: 2018;121-38.

23. Hamidu L, Ahmad AR, Najib A. Qualitative and quantitative test of total flavonoid buni fruit (Antidesma bunius (L.) Spreng) with UV-Vis spectrophotometry method. Pharmacogn J. 2018;10(1):60-3.

24. Suryanto. Phytochemical Antioxidant. Surabaya, Indonesia: Putra Media Nusantara; 2012 


\section{GRAPHICAL ABSTRACT}

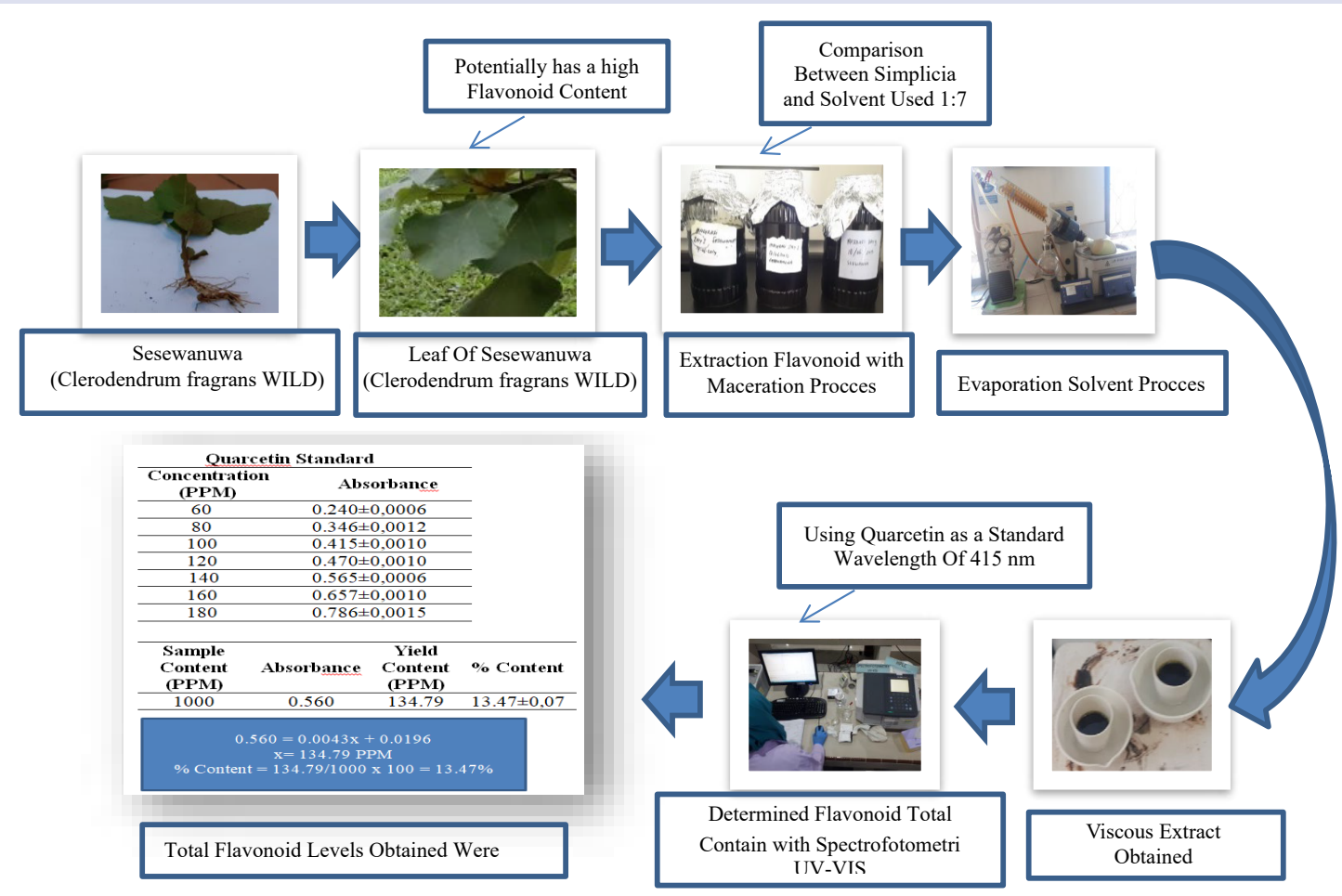

\section{ABOUT AUTHORS}

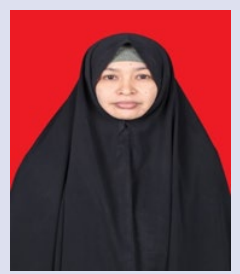

Zulfiayu Sapiun: Worked as a lecturer at the Polytechnic of the Ministry of Health in Gorontalo since 2014 and she has been the Chair of the Pharmacy Study Program of the Polytechnic of the Ministry of Health Gorontalo since 2018. She graduate from the Master of Pharmacy Science, Gadjah Mada University and currently focuses on research related to Pharmaceutical Technology with the use of natural ingredients as medicine. While serving as a lecturer at the Polytechnic of the Ministry of Health Gorontalo, she has made many contributions in managing institutions including in the field of research and publications both in national and international journals, as well as being active in Community Service activities and as oral presenters at national and international seminars. She has conducted research and published the results of her research, especially in the field of pharmaceutical technology, phytochemistry, and community pharmacy.

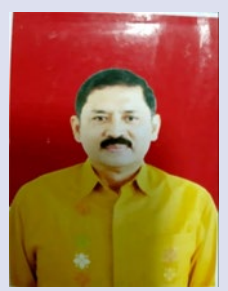

Paulus Pangalo: Worked as a lecturer at the Polytechnic of the Ministry of Health Gorontalo since 2015, and currently the Chair of the Research and Community Service Center of the Polytechnic of the inistry of Health Gorontalo. He graduate from Public Health at Hasanuddin University, Indonesia. His current field of work is health promotion and community empowerment. He is active in conducting research and publications in the fields of public health and community pharmacy.

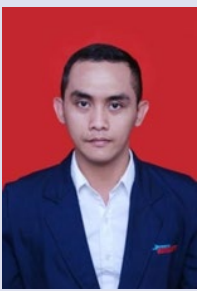

Arlan K.Imran: Graduated from the University of Setia Budi, Solo. Currently working as a lecturer in the Pharmacy Study Program of the Health Polytechnic of Gorontalo. The current field of work is phytochemistry. $\mathrm{He}$ is active in conducting research in the field of developing natural material activities and preparations and has published several journals related to the field of natural material formulations and activities. 


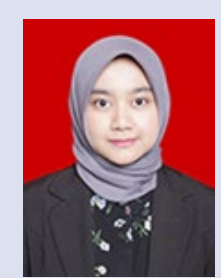

Prisca Safriani Wicita: Graduate of master program of Pharmacy with concentration of Pharmacy and Pharmaceutical Technology at the University of Padjadjaran, Bandung. Currently working as a lecturer in the Pharmacy Study Program of the Poltekkes Gorontalo Ministry of Health. The current field of work is Pharmaceutical Technology. She is active in conducting research in the field of pharmaceuticals and pharmaceutical preparation technology and has published several research journals and review journals related to the field of pharmaceutical excipient development and nanoparticle pharmaceutical preparation technology.

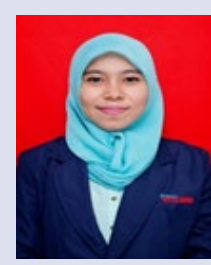

Rizka Puji Astuti Daud: Worked as Education Laboratory Staff at the Gorontalo Health Polytechnic since 2018, and currently is the general person in charge and equipment in the Pharmacy Health Polytechnic Study Program of Gorontalo Health Polytecnic Ministry of Health. She is graduate from the Pharmacist Profession at the University of Setia Budi and has conducted research in the field of pharmaceutical technology and pharmacology.

Cite this article: Sapiun Z, Pangalo P, Imran AK, Wicita PS, Daud RPA. Determination of Total Flavonoid Levels of Ethanol Extract Sesewanua Leaf (Clerodendrum Fragrans Wild) With Maceration Method Using UV-VIS Spectrofotometry. Pharmacog J. 2020;12(2):356-60. 